УДК 615.014.21/.771:615.453.6:615.322:582.688.3

DOI: $10.15587 / 2519-4852.2018 .128046$

\title{
INVESTIGATION OF THE EFFECTS OF EXCIPIENTS ON TECHNOLOGICAL PROPERTIES TABLETS OF ROUND-LEAVED WINTERGREEN EXTRACT
}

\author{
(C) N. Darzuli, T. Hroshovyi, K. Sokolova, E. Podpletnyaya
}

\begin{abstract}
Мета. Вивчення впливу допоміжних речовин на фармако-технологічні властивості таблеток екстракту грушанки круглолистої.

Методи. Об'єктом дослідження були 27 серій таблеток з екстрактом грушанки круглолистої . Вивчення впливу допоміжнх речовин на фармако-технологічні властивості таблеток а саме: стираність, міцність, розпадання, однорідність проводили згідно вимог ДФУ 2 видання. Зовнішній вигляд таблеток екстракту грушанки круглолистої очінювали за п'ятибальною шкалою.

Результати. При створенні таблеток методом прямого пресування вивчено вплив 27 ДР на фармакотехнологічні показники якості таблеток. Дослідження проведені з використаннням математичного планування експерименту - греко-латинського кубу 2-го порядку.

Результати дисперсійного аналізу експериментальних даних показали, щуо найвищу оцінку зовнішнього вигляду отримали таблетки при використанні неусілін US 2, vivapur 102, vivapur 112, парлітолу 100SD-манітолу.

Найкраще значення однорідності дозування таблеток з екстрактом грушанки круглолистої отримували при використанні крохмалю картопляного, кальцію гідрфосфату безводного, vivариг 302, парлітолу 300 DC -манітолу.

Найшвидше розпадалися таблетки з екстрактом грушанки круглолистої при використанні неусілін US 2, магнію стеарату, натрій кроскармелози, фловлаксу, vivapur 200, МКЦ бурсту, vivapur 302.

Найбільше значення міцності таблеток з екстрактом грушанки круглолистої отримували при використанні натрій кроскармелози, таблетози 80, procolv SMCC 90.

Найнижчу стиранність таблеток з екстрактом грушанки круглолистої забезпечують неусілін US 2 , кальиію стеарат, натрій кроскармелоза, procolv EASYtab SP, таблетоза 80.

Узагальнений показник функиї бажаності дозволив відібрати оптимальні рівні факторів (ДР) з кожної групи факторів: неусілін US 2, магнію стеарат, натрій кроскармелоза, procolv EASYtab SP, фловлакс.

Висновки. За допомогою греко-латинського кубу 2-го порядку вивчено вплив 27-ми ДР на фармакотехнологічні властивості таблеток (зовнішній вигляд, однорідність дозування, розпадання, міцність та стираність) і узагальнений показник - функцію бажаності. Результати експерименту дозволили обрати оптимальні ДР для подальших технологічних досліджень
\end{abstract}

Ключові слова: грушанка круглолиста, таблетки, математичне планування експерименту, рослинні екстракти, фармако-технологічні властивості таблеток

\section{Introduction}

In recent decades, phytotherapy has a stable position in the pharmaceutical market of medicines. According to statistics, more than $70 \%$ of the population of the planet at least once in the course of treatment used means of plant origin. Development of drug technology on the basis of medicinal plant material is an urgent task at present, since it has a mild pharmacotherapeutic effect, low toxicity, the ability to use it in a long time period and the absence of pronounced side effects [1]. The search for effective drugs for the treatment of diseases of the urinary system is particularly important, since this problem is not resolved until the end [2].

As a rule, phytodrugs possess a complex of pharmacotherapeutic effects. For example, round-leaved wintergreen has antimicrobial, anti-inflammatory, diuretic and nephroprotective effects, which makes it very promising as an object on the basis of which new drugs for treating diseases of the urinary system can be created [3].

2. Formulation of the problem in a general way, the relevance of the theme and its connection with important scientific and practical issues

Currently, for most systemic drugs, the best form of choice is tablets. Tablet preparations have a number of advantages, such as: ease of use, precision of dosing, portability, stability in storage, the ability to mask unpleasant odour and taste [4]. These advantages make tablets as a medicinal form of choice in the treatment of both acute conditions and chronic diseases. The development of new technologies in pharmacy opened up opportunities for improving the production of tablet drugs and their modifications $[4,5]$.

3. Analysis of recent studies and publications in which a solution of the problem are described and to which the author refers

The development of the technology of tablets based on plant extracts requires the adoption of optimal solutions for the selection of technological techniques and excipients that will be used. Plant extracts have unsatisfactory pharmacological and technological properties, therefore the choice of the method of preparation of tablets is chosen especially carefully, taking into account the pharmacological and technological parameters of the selected extract. As a rule, the method of wet granulation is used to develop the technology of tablets based on plant extracts $[6,7]$. Today the market has about 6000 names of modern excipients, which allows changing approaches to the development of technology tablets, which include API with unsatisfactory pharmacological and technological properties [5]. In case of rational use of excipient, it is possible to provide excellent pharma- 
co-technological properties of powder mixtures and to further ensure the quality of tablets in accordance with the requirements of the State Pharmacopoeia of Ukraine (SPhU), which will allow the use of direct compression as a method for obtaining tablets in many cases.

\section{The field of research considering the general problem, which is described in the article}

Despite the large number of excipients and the development of science, it is not always possible to determine the effect of excipients on a specific quality indicator of tablets, and to select optimal excipients. Chaotic addition and combination of excipients does not show the interrelationships and dependencies in the study of tablet formulations technology, which does not allow scientifically substantiate the technology of obtaining tablets. The use of mathematical planning of the experiment allows us to follow the interconnections and experimentally validate the influence of excipients on the pharmaco-technological indicators of the quality of Tablets $[8,9]$.

\section{Formulation of goals (tasks) of article}

To study the influence of excipients on the pharmacological and technological properties of tablets on the basis of dry round-leaved wintergreen extract obtained by direct compression.

6. Presentation of the main research material (methods and objects) with the justification of the results

In the development of tablet technology, a selfproduced dry c round-leaved wintergreen extract and excipients that meet the requirements of the State Pharmacopoeia of Ukraine (SPhU) and ensure the performance of all pharmacological and technological indicators of the quality of tablet formulations [10]. In our research, we used 27 certified excipients of domestic and foreign production (DP “OrisilKalush", Harke Pharma GmbH, JRS Pharma, Fuji Chemical Industri Co., Magnesia GmbH, Mingtai Chemical Co., Ltd. Roquette Pharma, Syntapharm, Südzucker) [11] . Microcrystalline cellulose samples (MCC) that we used, belong to the trademark Vivapur, the manufacturer is JRS Pharma.

Pharmaceutical factors and their levels that have been studied in order to select the rational excipient that provide the pharmacological and technological parameters of the quality of round-leaved wintergreen extract tablets are given in Table 1.

Table 1

Excipients that were studied when designed the composition of tablets on the basis of dry round-leaved wintergreen extract by direct compression.

\begin{tabular}{|c|c|}
\hline Factors & $\begin{aligned} \text { Levels of factors } \\
\end{aligned}$ \\
\hline$A$ - fillers based on inorganic salts & $\begin{array}{l}a_{1}-\text { neusilin US } 2 \\
a_{2}-\text { magnesium oxide granular } \\
a_{3}-\text { calcium hydrogen phosphate anhydrous }\end{array}$ \\
\hline$B$ - lubricants & $\begin{array}{l}b_{1}-\text { magnesium stearate } \\
b_{2}-\text { calcium stearate } \\
b_{3}-\text { sodium stearyl fumarate }\end{array}$ \\
\hline$C$ - expanders & $\begin{array}{l}c_{1}-\text { sodium croscarmellose } \\
c_{2}-\text { sodium carboxymethyl starch } \\
c_{3}-\text { potato starch }\end{array}$ \\
\hline $\begin{array}{l}D \text { - fillers based on MCC and its combina- } \\
\text { tion }\end{array}$ & $\begin{array}{l}d_{1}-\text { vivapur } 102 \\
d_{2}-\text { vivapur } 112 \\
d_{3}-\text { vivapur } 200 \\
d_{4}-\text { procolv SMCC } 90 \\
d_{5}-\text { procolv EASYtab SP } \\
d_{6}-\text { MCC burst } \\
d_{7}-\text { procolv ODT G2 } \\
d_{8}-\text { vivapur } 302 \\
d_{9}-\text { vivapur } 14 \\
\end{array}$ \\
\hline$E$-sugar-based fillers & $\begin{array}{l}e_{1}-\text { tabletose } 80 \\
e_{2}-\text { ludipres } \\
e_{3}-\text { pearlitol } 200 \mathrm{SD} \\
e_{4}-\text { Compri } \mathrm{M} 3 \\
e_{5}-\text { pearlitol } 100 \mathrm{SD}-\text { mannitol } \\
e_{6}-\text { pearlitol } 25 \mathrm{C} \\
e_{7}-\text { pearlitol } 300 \mathrm{DC}-\text { mannitol } \\
e_{8}-\text { flovelaks } \\
e_{9}-\text { fructose }\end{array}$ \\
\hline
\end{tabular}

When obtained tablets of round-leaved wintergreen with direct compression method for studying the effect of 27 excipients on the pharmaco-technological parameters of the tabletting mixtures, a Graeco-Latin square of the 2 nd order was used and 5 factors were studied, three of which were taken at 3 levels, and two of them at 9 levels [12].

In this case, instead of $2187(3 \times 3 \times 3 \times 9 \times 9=2187)$, a series of experiments that need to be implemented in a traditional experiment, when a complete overview of all 
possible combinations between levels of 5 factors, is implemented, only 54 series of experiments $(27$ series in two replicates) are implemented.

Excipients are divided into factors according to certain criteria, namely, their relation to a certain technological classification - fillers based on inorganic salts (factor A), lubricants (factor B), expanders (factor C), fillers based on MCC and its combinations (factor D), sugar-based fillers (factor E).

Powder masses were prepared according to the classic tablet production scheme. In order to develop the optimal composition of tablets with round-leaved wintergreen extract by direct compression, the following technological operations were used: sifting, weighing, mixing, powdering, pressing. The model mixtures were prepared as follows: all the necessary components were weighed, sieved, to a sugar-based filler a weighed active ingredient was added - the round-leaved wintergreen dried extract was mixed, the filler was introduced on the basis of microcrystalline cellulose, the mixture was again stirred, the filler on the basis of inorganic salts was added, mixed to homogeneity, expander was added and washed with a lubricant. The mixture of powders was mixed, a portion of the powder mixture was compressed on a laboratory tablet machine with a diameter of $12 \mathrm{~mm}$ punches and a weight of 0.6 grams; the resulting tablets were examined for compliance with the appearance (y1) and homogeneity of the dosage (y2). The remaining powder mixture was pressed on a handheld tablet press at a pressure of $50 \mathrm{~N}$ using a diameter of $12 \mathrm{~mm}$ punches and a fixed weight of one tablet of 0.6 grams. The resulting pills were tested for compliance with the pharmacotechnological quality indices such as: disintegration (y3), strength (y4), erase (y5). Conclusions on the choice of optimal auxiliary substances were made using the desirability function (y6).

The experimental design matrix and the results of the study of the pharmacological and technological parameters of the pills in each series of experiments were implemented in two replicates and presented in Table 2.

The results obtained were subjected to a dispersion analysis according to the scheme of a five-factor experiment, the computational procedure of which is given in the monograph [12]. In those cases where the experimental value of the F-criterion was more tabular, they made conclusions about the statistical significance of the investigated factor, constructed drawings, and discussed the obtained results. In the case where the F-criterion was less tabular, it was taken into account that there is no difference between the levels of the insignificant factor and the investigated indicator. This means that any excipient of the studied group gives the same result on the studied quality index of powder masses and the tablet tabletting process.

After pressing of tablets on the basis of dry roundleaved wintergreen extract, an evaluation of the appearance of tablets on a five-point scale was performed.

The dispersion analysis of experimental data showed that the appearance of the tablets is influenced by three of the five studied factors. The influence of factors on the investigated quality index of tablets with roundleaved wintergreen extract can be illustrated by the fol- lowing: $A>D>E$, with the insignificance of the factors $C$ and $\mathrm{B}$.

Among the studied inorganic salt-based fillers, the best estimates of the appearance of tablets based on round-leaved wintergreen extract provide neusilin US 2 (4.5 points) and calcium anhydrous hydrophosphate (4.5 points), which have an advantage over granulated magnesium oxide (3.9 points) )

The influence of D factor microcrystalline cellulose-based fillers on the appearance of the tablets can be represented by the following ranking of benefits: vivapur 102 (4.7 points) $>$ vivapur 112 (4.7 points) $>$ procolvSMCC 90 (4.5 points) $>$ vivapur 302 (4.5 points) $>$ procolv EASYtab SP (4.5 points) $>$ vivapur 14 (4.3 points) $>$ MCC bursts (4.3 points) $>$ procolv ODT G2 (3.8 points) $>$ vivapur 200 (3.5 points)

The nature of sugar-based fillers has a significant effect on the appearance of the tablets. The best appearance is provided by pearlitol 100 SD-mannitol (5 points), followed by ludipres (4.6 points), which have an advantage over pearlitol 200SD (4.5 points), flovelaks (4.5 points), tabletose 80 (4.3 points), pearlitol 300 DCmannitol (4 points), fructose (4 points), pearlitol $25 \mathrm{C}$ (4 points), compri M3 (3.8 points).

Homogeneity of dosing is a pharmacotechnological indicator of the quality of tablets, which should not exceed $5 \%$ in accordance with the requirements of the State Pharmacopoeia.

The influence of the factors studied on the homogeneity of dosage of tablets based on the round-leaved wintergreen extract has the following form: $\mathrm{E}>\mathrm{C}>\mathrm{D}>\mathrm{A}$ with factor $\mathrm{B}$ as insignificant.

The highest homogeneity of the dosage of tablets with round-leaved wintergreen extract among studied sugar-based fillers is observed with pearlitol 300 DCmannitol $(0.68 \%)$ which has an advantage over ludipres (0.93\%), flovelaks (0.94\%), compri M3 (0.97\%), pearlitol 100SD-mannitol $(1.06 \%)$, tabletose 80 (1.28\%), fructose $(1.29 \%)$, pearlitol 200SD $(1.30 \%)$, pearlitol $25 \mathrm{C}(2,1 \%)$

The effect of expanders on homogeneity of dosage of tablets with round-leaved wintergreen extract can be represented by the following ranged set of benefits: potato starch $(0.97 \%)>$ sodium carboxymethyl starch $(1.20 \%)>$ sodium croscarmellose $(1.38 \%)$.

The effect of microcrystalline cellulose fillers on the homogeneity of tablet dosage can be represented by the following ranking of several benefits: vivapur 302 $(0.81 \%)>$ vivapur $200(0.99 \%)>$ procolv EASYtab SP $(1.06 \%)>$ procolvSMCC $90(1,13 \%)>$ vivapur 14 $(1.17 \%)>$ MCC bourst $(1.25 \%)>$ vivapur $102(1.35 \%)>$ procolv ODT G2 (1.41\%)> vivapur $112(1.48 \%)$.

In the study of the influence of fillers on the basis of inorganic salts on the uniformity of dosage of roundleaved wintergreen extract tablets, the following results were obtained: calcium hydrophosphate anhydrous $(1.06 \%)$, magnesium oxide granulated $(1.20 \%)$, neusilin US2 $(1.27 \%)$.

The time of disintegration of tablets with roundleaved wintergreen extract is an important quality indicator, according to the $\mathrm{SPhU}$, the disintegration time should not exceed 15 minutes. 
The influence of the factors studied on the disintegration of tablets can be represented as follows: $\mathrm{C}>\mathrm{E}>\mathrm{D}>\mathrm{A}>\mathrm{B}$.

The best values for the disintegration of roundleaved wintergreen extract tablets in the study of expander adjuvants were observed with sodium croscarmellose (7.0 min.), which has an advantage over sodium carboxymethyl starch (7.2 min.) and potato starch (11.0 min.).
The fastest disintegration of tablets with sugarbased fillers is provided by flovelaks $(7.0 \mathrm{~min}$.), followed by tabletose 80 (7.2 min.), that have an advantage over fructose (8.0 min.), compri M3 (8.2 min.), pearlitol 300 DC-mannitol (8.2 min.), pearlitol 100SD-mannitol (8.3 min.), pearlitol 200SD (8.3 min.), ludipres (10.2 min), pearlitol 25C (10.7 min.).

Experiment planning matrix and results of study of round-leaved wintergreen extract tablets

\begin{tabular}{|c|c|c|c|c|c|c|c|c|c|c|c|c|c|c|c|c|c|}
\hline \multirow{2}{*}{ No. } & \multicolumn{5}{|c|}{ Factors } & \multicolumn{12}{|c|}{ Reviews (indicators) } \\
\hline & $A$ & $B$ & $C$ & $D$ & $E$ & $\mathrm{y}_{1}$ & $\mathrm{y}_{1}$ & $\mathrm{y}_{2}$ & $\mathrm{y}_{2}$ & $\mathrm{y}_{3}$ & $\mathrm{y}_{3}$ & $\mathrm{y}_{4}$ & $\mathrm{y}_{4}$ & $\mathrm{y}_{5}$ & $\mathrm{y}_{5}$ & $\mathrm{D}$ & $\mathrm{D}^{\prime}$ \\
\hline 1 & $a_{1}$ & $b_{1}$ & $c_{1}$ & $d_{1}$ & $e_{1}$ & 5 & 4 & 1.91 & 1.79 & 6 & 6 & 185.2 & 164.2 & 0.1006 & 0.1004 & 0.939 & 0.913 \\
\hline 2 & $a_{1}$ & $b_{2}$ & $c_{1}$ & $d_{5}$ & $e_{2}$ & 5 & 5 & 0.91 & 0.77 & 7 & 8 & 172.7 & 175.3 & 0.1337 & 0.1345 & 0.947 & 0.945 \\
\hline 3 & $a_{1}$ & $b_{3}$ & $c_{1}$ & $d_{9}$ & $e_{3}$ & 4 & 5 & 1.88 & 1.54 & 6 & 6 & 197.7 & 191.5 & 0.1671 & 0.1698 & 0.917 & 0.939 \\
\hline 4 & $a_{2}$ & $b_{1}$ & $c_{1}$ & $d_{2}$ & $e_{4}$ & 4 & 4 & 1.38 & 1.45 & 7 & 7 & 153.8 & 153.5 & 0.1999 & 0.1982 & 0.903 & 0.903 \\
\hline 5 & $a_{2}$ & $b_{2}$ & $c_{1}$ & $d_{6}$ & $e_{5}$ & 5 & 5 & 1.01 & 1.27 & 6 & 6 & 103.7 & 105.8 & 0.2671 & 0.2676 & 0.681 & 0.716 \\
\hline 6 & $a_{2}$ & $b_{3}$ & $c_{1}$ & $d_{7}$ & $e_{6}$ & 3 & 3 & 2.97 & 2.11 & 14 & 13 & 121.2 & 124.3 & 0.3338 & 0.3387 & 0.537 & 0.617 \\
\hline 7 & $a_{3}$ & $b_{1}$ & $c_{1}$ & $d_{3}$ & $e_{7}$ & 4 & 4 & 0.45 & 0.74 & 6 & 6 & 138.0 & 106.7 & 0.2697 & 0.2656 & 0.913 & 0.714 \\
\hline 8 & $a_{3}$ & $b_{2}$ & $c_{1}$ & $d_{4}$ & $e_{8}$ & 5 & 5 & 1.38 & 1.23 & 5 & 6 & 147.9 & 140.8 & 0.2004 & 0.2016 & 0.925 & 0.915 \\
\hline 9 & $a_{3}$ & $b_{3}$ & $c_{1}$ & $d_{8}$ & $e_{9}$ & 5 & 5 & 0.88 & 1.08 & 6 & 6 & 145.0 & 148.3 & 0.1330 & 0.1374 & 0.935 & 0.933 \\
\hline 10 & $a_{1}$ & $b_{1}$ & $c_{2}$ & $d_{4}$ & $e_{9}$ & 4 & 5 & 1.33 & 1.83 & 8 & 7 & 170.4 & 177.1 & 0.0999 & 0.0943 & 0.915 & 0.934 \\
\hline 11 & $a_{1}$ & $b_{2}$ & $c_{2}$ & $d_{8}$ & $e_{7}$ & 4 & 4 & 1.10 & 0.83 & 7 & 7 & 111.0 & 81.2 & 0.2001 & 0.2056 & 0.757 & 0.513 \\
\hline 12 & $a_{1}$ & $b_{3}$ & $c_{2}$ & $d_{3}$ & $e_{8}$ & 4 & 4 & 1.24 & 0.85 & 6 & 6 & 136.0 & 131.1 & 0.2002 & 0.2034 & 0.899 & 0.893 \\
\hline 13 & $a_{2}$ & $b_{1}$ & $c_{2}$ & $d_{5}$ & $e_{3}$ & 4 & 4 & 1.14 & 1.36 & 7 & 6 & 125.8 & 130.9 & 0.1674 & 0.1653 & 0.871 & 0.880 \\
\hline 14 & $a_{2}$ & $b_{2}$ & $c_{2}$ & $d_{9}$ & $e_{1}$ & 4 & 4 & 0.81 & 1.02 & 6 & 6 & 119.7 & 111.2 & 0.2336 & 0.2356 & 0.837 & 0.760 \\
\hline 15 & $a_{2}$ & $b_{3}$ & $c_{2}$ & $d_{1}$ & $e_{2}$ & 5 & 4 & 1.35 & 1.12 & 10 & 9 & 130.0 & 134.6 & 0.2009 & 0.2065 & 0.867 & 0.879 \\
\hline 16 & $a_{3}$ & $b_{1}$ & $c_{2}$ & $d_{6}$ & $e_{6}$ & 4 & 4 & 1.83 & 1.97 & 7 & 7 & 115.7 & 113.4 & 0.3336 & 0.3365 & 0.786 & 0.765 \\
\hline 17 & $a_{3}$ & $b_{2}$ & $c_{2}$ & $d_{7}$ & $e_{4}$ & 3 & 4 & 0.84 & 0.75 & 8 & 8 & 119.4 & 121.3 & 0.2005 & 0.2021 & 0.690 & 0.845 \\
\hline 18 & $a_{3}$ & $b_{3}$ & $c_{2}$ & $d_{2}$ & $e_{5}$ & 5 & 5 & 1.3 & 0.98 & 7 & 8 & 130.6 & 141.8 & 0.2001 & 0.2012 & 0.893 & 0.920 \\
\hline 19 & $a_{1}$ & $b_{1}$ & $c_{3}$ & $d_{7}$ & $e_{5}$ & 5 & 5 & 0.83 & 0.96 & 12 & 11 & 138.5 & 145.9 & 0.1672 & 0.1665 & 0.852 & 0.890 \\
\hline 20 & $a_{1}$ & $b_{2}$ & $c_{3}$ & $d_{2}$ & $e_{6}$ & 5 & 5 & 1.85 & 1.89 & 12 & 11 & 175.4 & 172.1 & 0.1335 & 0.1343 & 0.854 & 0.887 \\
\hline 21 & $a_{1}$ & $b_{3}$ & $c_{3}$ & $d_{6}$ & $e_{4}$ & 4 & 4 & 0.76 & 0.64 & 10 & 9 & 122.6 & 128.1 & 0.2343 & 0.2364 & 0.830 & 0.872 \\
\hline 22 & $a_{2}$ & $b_{1}$ & $c_{3}$ & $d_{8}$ & $e_{8}$ & 5 & 4 & 0.42 & 0.54 & 9 & 10 & 136.7 & 114.6 & 0.3331 & 0.3346 & 0.909 & 0.768 \\
\hline 23 & $a_{2}$ & $b_{2}$ & $c_{3}$ & $d_{3}$ & $e_{9}$ & 3 & 2 & 1.16 & 1.48 & 11 & 10 & 130.2 & 139.7 & 0.2653 & 0.2685 & 0 & 0 \\
\hline 24 & $a_{2}$ & $b_{3}$ & $c_{3}$ & $d_{4}$ & $e_{7}$ & 4 & 4 & 0.54 & 0.44 & 11 & 12 & 143.3 & 144.3 & 0.2999 & 0.2932 & 0.871 & 0.836 \\
\hline 25 & $a_{3}$ & $b_{1}$ & $c_{3}$ & $d_{9}$ & $e_{2}$ & 5 & 4 & 0.81 & 0.64 & 13 & 14 & 164.5 & 163.8 & 0.1998 & 0.1987 & 0.830 & 0.790 \\
\hline 26 & $a_{3}$ & $b_{2}$ & $c_{3}$ & $d_{1}$ & $e_{3}$ & 5 & 5 & 1.14 & 0.78 & 13 & 12 & 131.5 & 139.2 & 0.2000 & 0.2014 & 0.790 & 0.850 \\
\hline 27 & $a_{3}$ & $b_{3}$ & $c_{3}$ & $d_{5}$ & $e_{1}$ & 4 & 5 & 1.26 & 0.94 & 10 & 9 & 148.6 & 141.4 & 0.1335 & 0.1365 & 0.879 & 0.916 \\
\hline
\end{tabular}

Notes: $y_{1}$ and $y_{1}$ are the appearance of the pills of the first and second series of experiments respectively, the point; $y_{2}$ and $y_{2}-$ homogeneity of dosage of tablets of the first and second series of experiments, \%; $y_{3}$ and $y_{3}-$ disintegration of tablets of the first and second series, respectively, min.; $y_{4}$ and $y_{4}-$ strength of tablets of the first and second series of experiments, respectively, $H ; y_{5}$ and $y_{5}{ }^{-}$- erasing of tablets of the first and second series accordingly, \%; D and $D^{\prime}-$ the function of the desirability of the first and second series respectively

The effect of microcrystalline cellulose-based fillers on tablet disintegration can be represented by the following ranked benefits: vivapur 302 (7.5 min.) = vivapur $200(7.5 \mathrm{~min})=$. MCC burst $(7.5 \mathrm{~min})>$. procolv EASYtab SP $7.8 \mathrm{~min})>$ procolvSMCC $90(8.2 \mathrm{~min})>$ vivapur $14(8.5 \mathrm{~min})>$ vivapur $112(8.7 \mathrm{~min})>$ vivapur $102(9.3 \mathrm{~min})>$ procolv ODT G2 $(11 \mathrm{~min})$.

The ranked number of advantages of the influence of fillers on the basis of inorganic salts on the disintegration of tablets with roundworm corn extract can be represented as follows: neusilin US $2(8.0 \mathrm{~min})>$ calcium hydrophosphate anhydrous $(8.3 \mathrm{~min})>$ granulated magnesium oxide ( $8.8 \mathrm{~min}$.).
The fastest disintegration of the tablets among the lubricants is provided with magnesium stearate $(8.3 \mathrm{~min}$.) and calcium stearate $(8.3 \mathrm{~min}$.), which has an advantage over sodium stearyl fumarate ( $8.8 \mathrm{~min}$.).

The dispersion analysis of experimental data showed that the strength of the tablets is influenced by all five studied factors. The influence of factors on the investigated quality index of tablets with round-leaved wintergreen extract can be illustrated by the following series: $\mathrm{A}>\mathrm{C}>\mathrm{D}>\mathrm{E}>\mathrm{B}$.

Among the studied inorganic salt-based fillers, the highest strength values of round-leaved wintergreen extract tablets provide neusilin US $2(154 \mathrm{~N})$, which has 
an advantage over calcium hydrophosphate anhydrous $(137 \mathrm{~N})$ and granulated magnesium oxide $(129 \mathrm{~N})$.

Among the studied expedients, the strongest tablets based on the round-leaved wintergreen extract are sodium croscarmellose $(149 \mathrm{~N})$ and potato starch $(143 \mathrm{~N})$, which have a slight advantage over sodium carboxymethyl starch $(128 \mathrm{~N})$.

The effect of D-fillers on the basis of microcrystalline cellulose on the strength of the tablets can be represented by the following ranked range of benefits: procolvSMCC $90(97 \mathrm{~N})>$ procolv EASYtab SP $(96 \mathrm{~N})$ $>$ vivapur $102(95 \mathrm{~N})=$ vivapur $112(95 \mathrm{~N})=$ vivapur $302(95 \mathrm{~N})=$ vivapur $14(95 \mathrm{~N})>$ procolv ODT G2 $(93$ $\mathrm{N})=\operatorname{vivapur} 200(93 \mathrm{~N})>\mathrm{MCC}$ burst $(90 \mathrm{~N})$.

The nature of sugar-based fillers affects the strength of tablets with round-leaved wintergreen extract in the following way. The highest strength is provided by the ludipres $(156 \mathrm{~N})$, followed by pearlitol 200SD $(152 \mathrm{~N})$ and fructose $(151 \mathrm{~N})$, which have an advantage over tabletose $80(145 \mathrm{~N})$ pearlitol $25 \mathrm{C}(137 \mathrm{~N})$, flovelaks(134 N), compri M3 $(133 \mathrm{~N})$, pearlitol $100 \mathrm{SD}$ mannitol $(127 \mathrm{~N})$ and pearlitol $300 \mathrm{DS}$ mannitol $(120 \mathrm{~N})$.

Magnesium stearate $(144 \mathrm{~N})$, which has an advantage over sodium stearyl fumarate $(142 \mathrm{~N})$ and calcium stearate $(133 \mathrm{~N})$, provides the best strength of the tablets among the lubricants.

The influence of excipients on the erosion of roundleaved wintergreen extract tablets can be represented by the following series of advantages: $\mathrm{A}>\mathrm{D}>\mathrm{E}>\mathrm{C}>\mathrm{B}$.

Among the studied fillers based on inorganic salts, the lowest values of the erosion of the round-leaved wintergreen extract provide neusilin US $2(0.16 \%)$, which has an advantage over calcium hydrophosphate anhydrous $(0.21 \%)$ and granulated magnesium oxide $(0.26 \%)$.

Fillers based on microcrystalline cellulose on the indicator of erosion of tablets with round-leaved wintergreen extract are influenced as follows. The lowest level of erosion is provided by procolv EASYtab SP $(0.145 \%)$, which has the advantage over vivapur $102(0.168 \%)$, vivapur 112 $(0.178 \%)$, procolvSMCC $90(0.198 \%)$, vivapur 14 $(0.201 \%)$, vivapur $302(0.224 \%)$, procolv ODT G2 (0.235\%), vivapur $200(0.246 \%)$, MCC burst (0.279\%).

In the study of tablets based on a round-leaved wintergreen extract, a number of advantages over sugarbased fillers have the following form: tabletose 80 $(0.157 \%)>$ fructose $(0.166 \%)>$ pearlitol $200 \mathrm{SD}$ $(0.178 \%)>$ ludipres $(0.179 \%)>$ pearlitol $100 \mathrm{SD}$ - mannitol $(0.211 \%)>$ compri M3 $(0.212 \%)>$ flovelaks $(0.246 \%)>$ pearlitol $300 \mathrm{DC}-$ mannitol $(0.256 \%)>$ pearlitol 25C $(0.268 \%)$.

Among the studied expedients, the slightest erosion of tablets based on the round-leaved wintergreen extract is provided by sodium croscarmellose $(0.201 \%)$, which has a slight advantage over sodium carboxymethyl starch $(0.205 \%)$ and potato starch $(0.219 \%)$.

Calcium stearate $(0.205 \%)$, which has an advantage over magnesium stearate $(0.207 \%)$ and sodium stearyl fumarate $(0.213 \%)$, provides the slightest erosion of tablets among lubricants.

The results of studies have shown that in studying the influence of excipients on the pharmacological and technological indicators of quality of tablets, we obtained different ranks of advantages, which greatly complicates the choice of optimal excipients for the next stage of research.

In such cases, for a decision to choose the best excipients for the next experiment, it is rational to use a generalized indicator - a desirable function. For this purpose, the initial results of the reviews $\mathrm{y}_{1}-\mathrm{y}_{5}$ (Table 2) in the procedure described in the monograph [12] were translated into dimensionless quantities.

The obtained results of the desirability function were subjected to a dispersion analysis. On the basis of comparison of the mean values for the levels of the studied factors using the desirability function, we have obtained the following set of advantages: $A>B>D>E>C$.

Among the studied fillers based on inorganic salts, the highest values of the desirability function of tablets based on the round-leaved wintergreen extract provide neusilin US $2(0.872)$, which has an advantage over calcium with hydrophosphate anhydrous (0.849) and granulated magnesium oxide (0.713).

Magnesium stearate $(0.872)$, which has an advantage over calcium stearate $(0.849)$ and sodium stearyl fumarate $(0.713)$, provides the best indicators of the function of desirability among the lubricants.

Fillers based on microcrystalline cellulose on the combined index of the desirability function are as follows.

The best results has procolv EASYtab SP (0.906), which has an advantage over procolvSMCC 90 (0.899), vivapur 112 (0.893), vivapur 102 (0.873), vivapur 14 (0.846) vivapur $302(0.803)$, MCC burst $(0.775)$, procolv ODT G2 (0.739), vivapur 200 (0.570).

In the study of tablets based on the round-leaved wintergreen extract on the combined index of the desirability function, the ranked number of advantages among sugar-based fillers has the following form: flovlakes (0.885) $>$ ludipres $(0.876)>$ pearlitol 200SD (0.875) > tabletose $80(0.874)>$ compri M3 $(0.841)>$ pearlitol 100SD - mannitol $(0.825)>$ pearlitol $300 \mathrm{DC}-$ mannitol $(0.767)>$ pearlitol $25 \mathrm{C}(0.741)>$ fructose $(0.620)$.

Among the studied expedient substances, the best value for the function of the desirability of tablets based on the round-leaved wintergreen extract is sodium croscarmellose (0.850), which has an advantage over sodium carboxymethyl starch $(0.882)$ and potato starch (0.757).

Experiment results allowed to select the optimal levels of factors (excipients) from each group of factors. So, from the group of fillers based on inorganic salts, the best quality indicators provide neusilin US 2, from the group of lubricants - magnesium stearate, from the group of expedient agents - sodium croscarmellose.

The best results in the group of fillers on the basis of MCC showed procolv EASYtab SP, and from the group of fillers based on sugars - flovelaks. The above mentioned excipients were selected for further research in order to develop the optimal composition of tablets based on round-leaved wintergreen extract. 
7. Conclusions from the conducted research and prospects for further development of this field

1. With the help of the Graeco-Latin square of the 2nd order, the influence of the 27 excipients on the pharmaco-technological properties of the tablets (appear- ance, homogeneity of dosage, disintegration, strength and erosion) and the generalized index - the function of desirability were studied.

2. The experimental results allowed to select optimal excipients for further technological research.

\section{References}

1. Hromovyk B. P., Yurchenko E. V, Pavlychko S. S. Monytorynh otnoshenyia potrebytelei k prymenenyiu preparatov rastytelnoho proyskhozhdenyia // Provyzor. 2000. Issue 14. P. 14-16.

2. Darzuli N., Denys A., Hroshovyi T. Marketing research of the market of drugs and dietary supplements used for treatment of inflammatory diseases of the urinary system // Pharmaceutical review. 2017. No. 4. P. 76-81. doi: 10.11603/23120967.2017.4.8376

3. Darzuli N. P., Hroshovyi T. A. Vykorystannia hrushanky kruhlolystoi v medytsyni ta farmatsii, perspektyvy stvorennia novykh likarskykh zasobiv na yii osnovi // Fitoterapiia. Chasopys. 2015. Issue 3. P. 55-58.

4. Allen L., Ansel H. Pharmaceutical Dosage Forms and Drug Delivery

Systems. Philadelphia-Baltimore-New York, 2014. 794 p.

5. Khadzhieva Z. D., Kuznetsov A. V., Biryukova D. V. Tekhnologicheskie aspekty ispol'zovaniya vspomogatel'nykh veshhestv v proizvodstve lekarstvennykh preparatov. Fundamental'nye issledovaniya. 2012. Issue 5. P. 436-440.

6. Chuyeshov V. I., Hladukh Ye. V., Sayko I. V. Tekhnolohiya likiv promyslovoho vyrobnytstva. Part 1. Kharkiv: NfaU, Oryhinal, 2012. 694 p.

7. Encyclopedia of Pharmaceutical Technology / ed. by J. Swarbrick. New York: Informa Healthcare USA, 2007. 4372 p.

8. Hureieva S. M. Vybir dopomizhnykh rechovyn z metoiu rozrobky skladu tabletok z amizonom // Klinichna farmatsiia, farmakoterapiia ta medychna standartyzatsiia. 2015. Issue 1-2 (26-27). P. 32-38.

9. Bekchanov Kh. K., Usubbaev A. M., Usubbaev M. U. Optimizatsiya sostava i razrabotka tekhnologii tabletok "Mumifer" s primeneniem metoda matematicheskogo planirovaniya eksperimenta // Khimiko-farmatsevticheskiy zhurnal. 2005. Vol. 39 , Issue 5. P. 46-48.

10. Derzhavna Farmakopeia Ukrainy. Vol. 1. Kharkiv: Derzhavne pidpryiemstvo «Ukrainskyi naukovyi farmakopeinyi tsentr yakosti likarskykh zasobiv», 2015. 1135 p. 2016. $720 \mathrm{p}$.

11. Dopomizhni rechovyny u vyrobnytstvi likiv: textbook / Ruban O. A. et al.; ed. by Pertsev I. M. Kharkiv: Zoloti storinky,

12. Matematychne planuvannia eksperymentu pry provedenni naukovykh doslidzhen $\mathrm{v}$ farmatsii / Hroshovyi T. A. et al.; ed. by Hroshovyi T. A. Ternopil: Ukrmedknyha, 2008. 367 p.

Дата надходження рукопису 20.03.2018

Natalia Darzuli, Assistant, Department of Pharmacy Management, Economics and Technology, State Higher Educational Institution "I. Horbachevsky Ternopil State Medical University of Ministry of Health of Ukraine", Voli sq., 1, Ternopil, Ukraine, 46001

E-mail: darzulinp@tdmu.edu.ua

Taras Hroshovyi, Doctor of Pharmaceutical Sciences, Professor, Head of Department, Department of Pharmacy Management, Economics and Technology, State Higher Educational Institution "I. Horbachevsky Ternopil State Medical University of Ministry of Health of Ukraine", Voli sq., 1, Ternopil, Ukraine, 46001

Kateryna Sokolova, PhD, Associate professor, Departments of General and Clinical Pharmacy, State Establishment "Dnipropetrovsk Medical Academy of Ministry of Health of Ukraine" , Volodymyra Vernadskoho str., 9, Dnipro, Ukraine, 49044

E-mail: cat@dma.dp.ua

Elena Podpletnyaya, Doctor of Pharmaceutical Sciences, Professor, Head of Department, Departments of General and Clinical Pharmacy, State Establishment "Dnipropetrovsk Medical Academy of Ministry of Health of Ukraine", Volodymyra Vernadskoho str., 9, Dnipro, Ukraine, 49044

E-mail: e_podpl@ukr.net 